Original Article

\title{
Amazonian soil fungi are efficient degraders of glyphosate herbicide; novel isolates of Penicillium, Aspergillus, and Trichoderma
}

\author{
Os fungos do solo amazônico são degradadores eficientes do herbicida glifosato; novos \\ isolados de Penicillium, Aspergillus e Trichoderma
}

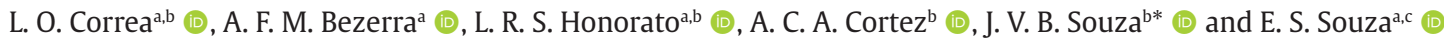 \\ aUniversidade do Estado do Amazonas - UEA, Escola Superior de Ciências da Saúde, Manaus, AM, Brasil \\ 'Instituto Nacional de Pesquisas da Amazônia - INPA, Laboratório de Micologia, Manaus, AM, Brasil \\ cUniversidade do Estado do Amazonas - UEA, Escola Superior de Tecnologia, Manaus, AM, Brasil
}

\begin{abstract}
Pesticide residues that contaminate the environment circulate within the hydrological cycle can accumulate within the food chain and cause problems to both environmental and human health. Microbes, however, are well known for their metabolic versatility and the ability to degrade chemically stable substances, including recalcitrant xenobiotics. The current study focused on bio-prospecting within Amazonian rainforest soils to find novel strains fungi capable of efficiently degrading the agriculturally and environmentally ubiquitous herbicide, glyphosate. Of 50 fungal strains isolated (using culture media supplemented with glyphosate as the sole carbon-substrate), the majority were Penicillium strains (60\%) and the others were Aspergillus and Trichoderma strains (26 and $8 \%$, respectively). All 50 fungal isolates could use glyphosate as a phosphorous source. Eight of these isolates grew better on glyphosate-supplemented media than on regular Czapek Dox medium. LC-MS revealed that glyphosate degradation by Penicillium 4A21 resulted in sarcosine and aminomethylphosphonic acid.
\end{abstract}

Keywords: amazonian soil fungi, Aspergillus, bioremediation, degradation of xenobiotics, glyphosate, Penicillium, recalcitrant compounds, Trichoderma.

\begin{abstract}
Resumo
Resíduos de agrotóxicos que contaminam o meio ambiente circulam no ciclo hidrológico, podendo se acumular na cadeia alimentar e causar problemas tanto à saúde ambiental quanto humana. Por sua vez, microrganismos são bem conhecidos por sua versatilidade metabólica e capacidade de degradar substâncias quimicamente estáveis, incluindo xenobióticos recalcitrantes. $\mathrm{O}$ estudo atual se concentrou na bioprospecção nos solos da floresta amazônica para encontrar novas linhagens de fungos capazes de degradar com eficiência o herbicida onipresente na agricultura e no meio ambiente, o glifosato. Entre os 50 fungos isolados (usando meio de cultura suplementado com glifosato como única fonte de carbono), a maioria eram isolados do gênero Penicillium (60\%) e os outros eram isolados de Aspergillus e Trichoderma (26 e 8\%, respectivamente). Todos os 50 isolados de fungos foram capazes de usar glifosato como fonte de fósforo. Oito desses isolados cresceram melhor em meio suplementado com glifosato do que em meio Czapek Dox regular. LC-MS revelou que a degradação do glifosato por Penicillium 4A21 resultou nos metabólitos sarcosina e ácido aminometilfosfônico.
\end{abstract}

Keywords: fungos do solo amazônico, Aspergillus, biorremediação, degradação de xenobióticos, glifosato, Penicillium, compostos recalcitrantes, Trichoderma.

\section{Introduction}

The need for global food security is now more urgent than at any time in human history, and yet the need to protect environmental and human health are both necessary and challenging (Sharma et al., 2019). These, sometimes opposing, forces underlie the conflict between the need to intensify agriculture while avoiding poisoning the Earth's ecosystems, including the food supply chain with pesticides and other agricultural chemicals (Sharma et al., 2019). There are over 14.1 million new cancer cases each year worldwide, many of these because of exposure to xenobiotics in the environment and food chain (Torre et al., 2015). For some decades, we have known that these xenobiotics circulate within the hydrological cycle and so contaminate diverse geographical regions indiscriminately, including otherwise

*e-mail: joao.souza@inpa.gov.br

Received: August 27, 2020 - Accepted: January 5, 2021 
pristine environments (Gasnier et al., 2009; Giesy et al., 2000; Monsanto, 2005; Van Bruggen et al., 2018). In some cases, it can influence the loss of biodiversity in different biomes, affecting the physiological performance of native plants not resistant to herbicides (Batista et al., 2018).

The current study was carried out towards easing this pollution load via an approached based bio-prospecting for novel microbial strains capable of effective and efficient degradation of xenobiotics as demonstrated in previous studies. We focused on glyphosate, a recalcitrant substance that has been applied as an herbicide that targets broad-leaved plants and grasses since 1974, throughout both temperate- and tropical regions (and is marketed under the name Roundup ${ }^{\circledR}$ ). Glyphosate is the agrochemical with the biggest sale in Brazil, totaling 217 metric tons per year (Krzyśko-Lupicka et al., 1997; Sviridov et al., 2015; Zhan et al., 2018). In 2015, analyses by the World Health Organization's International Agency for Research on Cancer and the European Food Safety Authority resulted in glyphosate being classed as genotoxic and cancer risk (Torre et al., 2015). However, the exact impacts on human health are subject to ongoing review and further research.

Microbes identified as glyphosate degraders are commonly isolated from contaminated soils; these include some bacteria but are mostly fungi species (Singh and Singh, 2016; Zhan et al., 2018). However, the phylogenetic range of strains/species known to degrade this herbicide and its toxic breakdown product, aminomethylphosphonic acid (AMPA), is limited, and the degradation is slow (Fu et al., 2017; Kaczyński and Łozowicka, 2015; Van Bruggen et al., 2018). The majority of the glyphosate-degrading fungi have been isolated from microbial habitats that are impoverished in terms of microbial diversity, such as cultivated agricultural soils (Arfarita et al., 2016; Klimek et al., 2001; Krzyśko-Lupicka et al., 1997). Therefore, we focused our bio-prospecting activities on pristine, high organic-matter soils of the Amazon rainforest, likely the most phylogenetically rich source of soil-based fungal saprobes in Earth's biosphere. We cast the net wide using a culture medium, supplemented with glyphosate to isolate any strain that can degrade this xenobiotic. The specific aims were to find fungi able to tolerate and degrade glyphosate. We discussed implications for glyphosate bioremediation and the potential for bio-prospecting for microbes capable of degrading other recalcitrant pollutants.

\section{Material and Methods}

\subsection{Glyphosate and analytical reagents}

Roundup ${ }^{\circledR}$ WG-Glyphosate (containing $0.720 \mathrm{~kg}$ glyphosate $/ \mathrm{kg}$ ) was obtained from Monsanto Agricultural Products Inc. (Creve Coeur, Missouri, U.S). AMPA and all other chemicals were obtained of the highest purity of analytical reagent grade commercially available (SigmaAldrich - St. Louis, Missouri, United States).

\subsection{Sampling soils and isolation of fungi}

Four soil samples were collected from the surface (1-10 cm depth) of the forest located at the Instituto Nacional de Pesquisas da Amazônia (INPA), Manaus, Amazonas, Brazil (Latitude-South $3^{\circ} 5^{\prime}$ 36" and Longitude West 59 59' 16").

Each soil sample (500 g) was homogenized with glyphosate $(0.1 \mathrm{~g})$ and incubated in a plastic box $(30 \times 40 \times 30 \mathrm{~cm})$ for 20 days, $25{ }^{\circ} \mathrm{C}$. After this period, the isolation of glyphosate-tolerant fungal strains was carried by Successive Serial Dilutions of soil in distillated water. Dilutions ( $100 \mu \mathrm{L}$ per dilution) were plated on the surface of Potato Dextrose Agar supplemented with glyphosate ( $2.35 \mathrm{~g} / \mathrm{L})$ and the plates were incubated for 7-10 days at $25{ }^{\circ} \mathrm{C}$. Fungal colonies were transferred and cultivated on Czapek Dox Agar. Micromorphological identifications were conducted according to taxonomy keys and literature (Fassatiowa, 1983; Pitt, 1979; Raper and Fennel, 1965).

\subsection{Evaluation of glyphosate assimilation as a phosphorus substrate source}

The evaluation of glyphosate assimilation as a phosphorus substrate source was based on the method previously described (Krzyśko-Lupicka et al., 1997; Arfarita et al., 2011) with some modifications. All the growth studies were carried out on Czapek Dox medium, which consisted of saccharose (30 g/L), $\mathrm{MgSO}_{4} .7 \mathrm{H}_{2} \mathrm{O}(0.5 \mathrm{~g} / \mathrm{L})$, $\mathrm{KCl}(0.5 \mathrm{~g} / \mathrm{L}), \mathrm{NaNO}_{3}(3 \mathrm{~g} / \mathrm{L}), \mathrm{FeSO}_{4}(0.01 \mathrm{~g} / \mathrm{L})$ and $\mathrm{KH}_{2} \mathrm{PO}_{4}$ $(1 \mathrm{~g} / \mathrm{L})$. The same medium, deficient in $\mathrm{KH}_{2} \mathrm{PO}_{4}$, was used as a control. When the glyphosate was used as the sole source of phosphorus, $\mathrm{KH}_{2} \mathrm{PO}_{4}$ in Czapek medium was replaced by glyphosate at a final concentration of $7.4 \mathrm{mM}$. If the starting $\mathrm{pH}$ of the medium was 6.0 or higher, it was not adjusted; when it was lower than 6.0 it was adjusted to 6.0 with $1 \mathrm{M}$ sodium hydroxide solution.

Bioprocess was carried out in $125 \mathrm{~mL}$ conical flasks containing $50 \mathrm{ml}$ standard or modified Czapek liquid medium. The cultures were inoculated with a spore suspension $\left(2 \times 10^{7}\right.$ spores $\left./ \mathrm{mL}\right)$ and incubated at $25^{\circ} \mathrm{C}$ on a shaking platform at $100 \mathrm{rev} . / \mathrm{min}$. After 14 days of incubation, the cultures were filtered and dry mass of the mycelium and $\mathrm{pH}$ of the medium was determined $(\mathrm{g} / \mathrm{L})$. The average values were obtained from three repetitions.

\subsection{Evaluation of glyphosate degradation}

\subsubsection{Ninhydrin reaction for glyphosate quantification}

The method used was proposed by Nagaraja and Bhaskara (2006), with some modifications. A calibration curve was prepared from a stock solution of $500 \mathrm{mg} / \mathrm{L}$ glyphosate. Aliquots ranging from 40 to $140 \mu \mathrm{L}$ were transferred to test tubes, and $500 \mu \mathrm{L}$ of $5 \%$ ninhydrin and $500 \mu \mathrm{L}$ of $5 \%$ sodium molybdate were added to each of the tubes. The tubes were sealed and kept in a water bath at $85-95{ }^{\circ} \mathrm{C}$ for 12 minutes. Then the samples were cooled to room temperature and were quantitatively transferred to $5 \mathrm{~mL}$ volumetric flasks. The volume was completed with distilled and deionized water. Then, the reading was performed by MultiSpec-1501, SHIMADZU spectrophotometer, at $570 \mathrm{~nm}$. We obtained a calibration 
curve with the absorbance as a function of glyphosate concentration ranging from 4 to $14 \mathrm{mg} / \mathrm{L}$. For the instrument's baseline, $500 \mu \mathrm{L}$ of ninhydrin and sodium molybdate solution was used, to a total volume of $5 \mathrm{~mL}$.

\subsection{LC-MS/MS analysis}

Shield RP C18 column (3.5- $\mu \mathrm{m}$ particle size, $150 \mathrm{~mm}$ in length, $2.1-\mathrm{mm}$ i.d.). The mobile phases consisted of Methanol: $\mathrm{H}_{2} \mathrm{O}(7: 3)$. Initial conditions were re-established in $1 \mathrm{~min}$ for a total run time of $15 \mathrm{~min}$. The column temperature was $35.0^{\circ} \mathrm{C}$, and the flow rate was $0.4 \mathrm{~mL} / \mathrm{min}$. We obtained the optimization of the ionization and fragmentation conditions for the analytes by the infusion of the individual analytes' solutions. Optimum responses were obtained by electrospray ionization in negative ion mode using the following source parameters: capillary voltage of $3.5 \mathrm{kV}$, cone voltage of $20 \mathrm{~V}$, source temperature of $120^{\circ} \mathrm{C}$, desolvation gas temperature of $350^{\circ} \mathrm{C}$ and gas flow of $160-200 \mathrm{~L} / \mathrm{h}$ (cone) and 580-600 L/h (desolvation).

\subsection{Statistical analysis}

All data were expressed as mean \pm standard error means (SEM). Statistical variance analyses were performed by Student's t-test using SPSS 20.0 for Windows (SPSS Inc., Chicago, IL). Differences at $P=0.05$ were considered statistically significant.

\section{Results}

Soil samples contaminated with glyphosate were diluted and transferred to culture media in order to isolate glyphosate tolerant fungi. The isolated microorganisms belonged to the Phylum Ascomycota, specifically the genus Penicillium (60.0\%), Aspergillus (26\%) and Trichoderma (8\%). It was not possible to identify $6 \%$ of the isolates (Table 1 ).

In order to investigate the ability of these isolates in using glyphosate as nutrient source, the isolates were grown in three different culture media (conventional Czapek medium, Czapek without $\mathrm{KH}_{2} \mathrm{PO}_{4}$, and Czapek without $\mathrm{KH}_{2} \mathrm{PO}_{4}$ but supplemented with glyphosate $(2.35 \mathrm{~g} / \mathrm{L})$ (Table 1$)$.

For this test interpretation, the fungi that produced more biomass in Czapek supplemented with glyphosate than in Czapek without $\mathrm{KH}_{2} \mathrm{PO}_{4}$ (control) are considered capable of using the herbicide formulation as a source of phosphorus. All isolates demonstrated the ability to use the herbicide formulation as a phosphorus source in the present work. Of these, eight isolates produced more biomass in Czapek supplemented with glyphosate than in conventional Czapek.

The glyphosate degradation (culture medium without $\mathrm{KH}_{2} \mathrm{PO}_{4}$ but supplemented with glyphosate) was investigated using ninhydrin reaction to quantify the glyphosate. Penicillium 4A21, Aspergillus 2B112 and Penicillium 2A31 promoted glyphosate degradations of $42.72 \pm 0.02$ (\%), $36.48 \pm 0.01$ and, $34.91 \pm 0.02$ in 14 days, respectively. LC-MS/MS demonstrated that glyphosate, AMPA and sarcosine could be found in culture filtrate of Penicillium 4A21 after 14 days of exposure to glyphosate (Figure 1).

\section{Discussion}

Our results demonstrated that most isolates from genera Penicillium, Aspergillus and Trichoderma probably used the herbicide formulation as a nutrient source. About $8 \%$ of the isolates grew better in the medium supplemented with the herbicide than in the conventional culture medium (Czapek). In addition, it was showed that the isolate Penicillium 4A21 produced AMPA and Sarcosine as metabolites from glyphosate degradation. This is the first study of screening for glyphosate degradation carried out with fungi isolated from the Amazon Forest soil.

It must be pointed out that extensive use of GP resulted in its accumulation in soil and water environments (Giesy et al., 2000; Monsanto, 2005; Van Bruggen et al., 2018). Moreover, negative effects of GP on animal metabolism have been reported, in particular, with respect to chronic and remote effects (Van Bruggen et al., 2018). In the present work, all the 50 isolates were able to use glyphosate as phosphorus source. The biomass assay described by Arfarita et al. (Arfarita et al., 2011) have previously been used as a robust methodology for the screening of microorganisms able to use glyphosate as nutrient source. A similar conclusion about this methodology was reached out by other workers with similar design (Arfarita et al., 2016; Carranza et al., 2016, 2017).

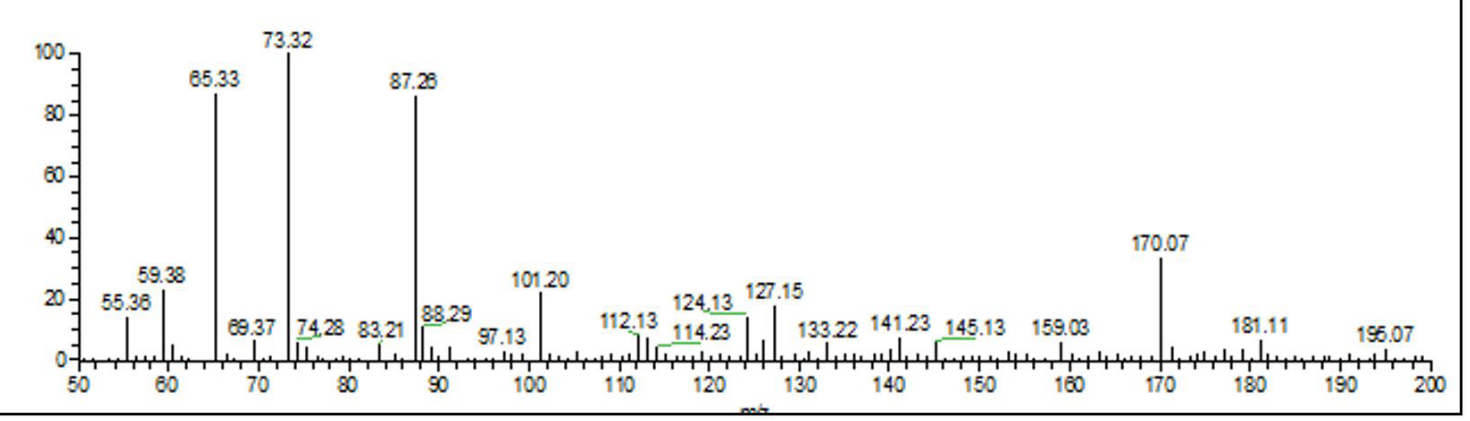

Figure 1. Mass spectrum resulting from the HPLC-MS of the isolated Penicillium 4A21 filtered. The filtrate presents possible peaks of glyphosate (170.07), AMPA (112.13) and sarcosine (89). 
Table 1. Biomass production after a 14-day incubation $\left(30^{\circ} \mathrm{C}\right)$ by the fungal isolates in three different culture media: a) conventional Czapek medium, b) Czapek without $\mathrm{KH}_{2} \mathrm{PO}_{4}$ and c) Czapek without $\mathrm{KH}_{2} \mathrm{PO}_{4}$ but supplemented with glyphosate (2.35 g/L). The fungal strains were isolated from soil collected from Amazon forest.

\begin{tabular}{|c|c|c|c|c|}
\hline \multirow[b]{2}{*}{ Isolate } & \multicolumn{4}{|c|}{ Biomass (g/L) } \\
\hline & CZ Medium & $\begin{array}{l}\text { CZ Medium without } \\
\qquad \mathrm{KH}_{2} \mathrm{PO}_{4}\end{array}$ & $\begin{array}{c}\text { CZ Medium } \\
\text { without } \mathrm{KH}_{2} \mathrm{PO}_{4} \\
\text { supplemented with } \\
\text { glyphosate }\end{array}$ & $\begin{array}{l}\text { Ratio (CZ Medium } \\
\text { without } \mathrm{KH}_{2} \mathrm{PO}_{4} \\
\text { supplemented with } \\
\text { glyphosate) / CZ } \\
\text { Medium) }\end{array}$ \\
\hline Penicillium 4A21 & $5.7 \pm 0.1$ & $4.4 \pm 0.4$ & $7.9 \pm 0.6$ & 1.32 \\
\hline Aspergillus 2B112 & $5.7 \pm 0.3$ & $4.1 \pm 0.5$ & $7.1 \pm 0.1$ & 1.24 \\
\hline Penicillium 2A31 & $5.2 \pm 1.2$ & $4.4 \pm 0.4$ & $6.2 \pm 0.1$ & 1.19 \\
\hline Penicillium $6 B 221$ & $6.6 \pm 1.4$ & $4.6 \pm 0.6$ & $7.6 \pm 0.8$ & 1.15 \\
\hline Penicillium 6 B112 & $4.7 \pm 0.6$ & $4.2 \pm 0.3$ & $5.2 \pm 0.4$ & 1.10 \\
\hline Penicillium 4A31 & $5.8 \pm 0.3$ & $2.8 \pm 0.3$ & $6.3 \pm 0.4$ & 1.08 \\
\hline Penicillium 4A211 & $6.91 \pm 0.02$ & $3.6 \pm 0.4$ & $7.1 \pm 0.4$ & 1.02 \\
\hline Penicillium $2 A 3$ & $6.4 \pm 0.9$ & $5.2 \pm 0.8$ & $6.4 \pm 0.4$ & 1.00 \\
\hline Penicillium 2B21 & $5.61 \pm 0.05$ & $4.1 \pm 0.2$ & $5.5 \pm 0.8$ & 0.98 \\
\hline Penicillium 6B21 & $4.9 \pm 0.3$ & $3.9 \pm 0.4$ & $4.8 \pm 0.4$ & 0.97 \\
\hline Penicillium 4A212 & $6.7 \pm 0.1$ & $4.31 \pm 0.07$ & $6.5 \pm 0.1$ & 0.97 \\
\hline Aspergillus $3 B 32$ & $6.6 \pm 0.3$ & $6.3 \pm 1.4$ & $6.4 \pm 1.4$ & 0.96 \\
\hline Aspergillus 5B21 & $6.4 \pm 0.4$ & $4.2 \pm 0.3$ & $6.2 \pm 0.1$ & 0.96 \\
\hline Aspergillus 3B411 & $6.3 \pm 0.8$ & $4.3 \pm 0.3$ & $6.1 \pm 0.2$ & 0.96 \\
\hline Penicillium 3B21 & $5.6 \pm 0.4$ & $4.3 \pm 0.5$ & $5.4 \pm 0.2$ & 0.96 \\
\hline Penicillium 5B114 & $6.6 \pm 0.1$ & $2.9 \pm 0.5$ & $6.3 \pm 0.3$ & 0.95 \\
\hline Trichoderma 2B11 & $6.6 \pm 0.1$ & $4.0 \pm 1.0$ & $6.3 \pm 0.4$ & 0.95 \\
\hline Penicillium 5B221 & $6.5 \pm 0.2$ & $4.2 \pm 0.2$ & $6.2 \pm 0.2$ & 0.95 \\
\hline Mycelium steridium $6 B 11$ & $6.6 \pm 0.1$ & $4.5 \pm 0.2$ & $6.2 \pm 0.3$ & 0.93 \\
\hline Penicillium 5A11 & $6.5 \pm 0.2$ & $4.2 \pm 1.2$ & $6.1 \pm 1.5$ & 0.93 \\
\hline Aspergillus 5B123 & $6.3 \pm 0.3$ & $4.2 \pm 1.4$ & $5.9 \pm 0.5$ & 0.93 \\
\hline Penicillium $5 B 112$ & $6.7 \pm 0.1$ & $4.4 \pm 0.2$ & $6.2 \pm 1.1$ & 0.92 \\
\hline Aspergillus 5B12 & $6.6 \pm 1.1$ & $4.8 \pm 1.1$ & $6.1 \pm 0.8$ & 0.92 \\
\hline Penicillium 2B41 & $6.4 \pm 0.4$ & $3.0 \pm 1.0$ & $5.9 \pm 0.7$ & 0.92 \\
\hline Aspergillus 2B51 & $6.9 \pm 0.1$ & $3.9 \pm 0.6$ & $6.3 \pm 0.8$ & 0.91 \\
\hline Aspergillus $3 A 53$ & $6.6 \pm 1.1$ & $4.0 \pm 1.0$ & $6.0 \pm 1.0$ & 0.90 \\
\hline Aspergillus $3 B 13$ & $8.3 \pm 2.3$ & $5.3 \pm 0.2$ & $7.5 \pm 0.3$ & 0.90 \\
\hline Aspergillus 3B42 & $6.2 \pm 0.2$ & $4.8 \pm 0.1$ & $5.6 \pm 0.1$ & 0.90 \\
\hline Penicillium 2 B311 & $6.8 \pm 0.3$ & $3.6 \pm 0.3$ & $6.1 \pm 0.6$ & 0.89 \\
\hline Penicillium 6B1 & $4.8 \pm 0.7$ & $2.8 \pm 0.4$ & $4.3 \pm 0.2$ & 0.89 \\
\hline Penicillium 4C12 & $6.9 \pm 0.6$ & $3.6 \pm 1.1$ & $6.1 \pm 0.3$ & 0.88 \\
\hline Aspergillus 3B23 & $4.61 \pm 0.02$ & $3.4 \pm 0.3$ & $4.0 \pm 1.0$ & 0.86 \\
\hline Penicillium 4 A213 & $6.5 \pm 0.1$ & $4.2 \pm 0.1$ & $5.6 \pm 0.1$ & 0.86 \\
\hline Penicillium 5B23 & $6.1 \pm 0.4$ & $4.2 \pm 0.2$ & $5.2 \pm 0.2$ & 0.85 \\
\hline Trichoderma 3C12 & $6.6 \pm 0.6$ & $4.1 \pm 0.4$ & $5.6 \pm 0.2$ & 0.84 \\
\hline Penicillium 3B41 & $5.8 \pm 0.3$ & $4.6 \pm 0.6$ & $4.9 \pm 0.4$ & 0.84 \\
\hline Aspergillus 3B231 & $6.4 \pm 1.5$ & $2.7 \pm 0.6$ & $5.3 \pm 0.6$ & 0.82 \\
\hline Penicillium 3B22 & $7.4 \pm 0.5$ & $4.2 \pm 0.2$ & $6.1 \pm 0.1$ & 0.82 \\
\hline
\end{tabular}


Table 1. Continued...

\begin{tabular}{|c|c|c|c|c|}
\hline \multirow[b]{2}{*}{ Isolate } & \multicolumn{4}{|c|}{ Biomass (g/L) } \\
\hline & CZ Medium & $\begin{array}{l}\text { CZ Medium without } \\
\qquad \mathrm{KH}_{2} \mathrm{PO}_{4}\end{array}$ & $\begin{array}{c}\mathrm{CZ} \text { Medium } \\
\text { without } \mathrm{KH}_{2} \mathrm{PO}_{4} \\
\text { supplemented with } \\
\text { glyphosate }\end{array}$ & $\begin{array}{c}\text { Ratio (CZ Medium } \\
\text { without } \mathrm{KH}_{2} \mathrm{PO}_{4} \\
\text { supplemented with } \\
\text { glyphosate) / CZ } \\
\text { Medium) }\end{array}$ \\
\hline Mycelium steridium $4 B 12$ & $7.6 \pm 0.4$ & $4.5 \pm 0.4$ & $6.2 \pm 0.1$ & 0.81 \\
\hline Penicillium 5B2 & $6.9 \pm 0.4$ & $3.3 \pm 0.6$ & $5.55 \pm 0.05$ & 0.79 \\
\hline Trichoderma $3 C 2$ & $7.7 \pm 0.7$ & $5.9 \pm 0.9$ & $6.1 \pm 1.4$ & 0.79 \\
\hline Penicillium 3C11 & $6.1 \pm 0.3$ & $4.5 \pm 0.9$ & $4.8 \pm 0.3$ & 0.78 \\
\hline Trichoderma $3 C 21$ & $7.3 \pm 0.8$ & $3.3 \pm 0.7$ & $5.7 \pm 0.5$ & 0.78 \\
\hline Penicillium 4B23 & $8.2 \pm 0.4$ & $4.3 \pm 0.1$ & $6.3 \pm 0.2$ & 0.76 \\
\hline Penicillium 5C21 & $6.5 \pm 0.3$ & $4.4 \pm 0.1$ & $4.9 \pm 0.3$ & 0.75 \\
\hline Penicillium 6C221 & $8.1 \pm 0.5$ & $3.9 \pm 0.5$ & $6.1 \pm 0.4$ & 0.75 \\
\hline Penicillium 5C211 & $8.7 \pm 2.8$ & $6.4 \pm 1.8$ & $6.5 \pm 0.8$ & 0.74 \\
\hline Penicillium 3C113 & $6.5 \pm 0.2$ & $3.8 \pm 0.4$ & $4.8 \pm 1.3$ & 0.73 \\
\hline Aspergillus 5B31 & $6.5 \pm 0.2$ & $4.3 \pm 0.3$ & $4.6 \pm 0.1$ & 0.70 \\
\hline $\begin{array}{l}\text { Mycelium } \\
\text { steridium } 3 C 112\end{array}$ & $6.3 \pm 0.5$ & $3.1 \pm 0.4$ & $3.9 \pm 0.6$ & 0.61 \\
\hline
\end{tabular}

The selected isolate Penicillium 4A21 degraded the herbicide glyphosate by over $42 \%$ in just 14 days in submerged fermentation. In soil, glyphosate degradation has different degradation rates. Wauchope et al. (1992) found that the half-life of glyphosate in soil can go up to 174 days. Carranza et al. (2019) reported that $50 \%$ of glyphosate was degraded by Aspergillus oryzae in soil microcosms in 28 days and $90 \%$ within 90 days. Monsanto (2005) conducted a study with agricultural and forest soils from five countries, and reported that the glyphosate half-life in soil ranges from two to 197 days, and AMPA 76 to 240 days. This suggests that the rate of the degradation of the glyphosate by filamentous fungi depends on culture media and bioprocess conditions.

At this stage of understanding, we believe Penicillium 4 A21 is a potential strain for glyphosate biodegradation, but other characteristics are important for a bioremediation microrganism, according to Maqbool et al. (2016) and Boopathy (2000). The microrganism used in bioremediation assays must have: (1) low toxicity and lack of pathogenicity, (2) high viability immediately after the introduction into environment in combination with low long-term survival rates, (3) high efficiency of GP degradation independent of external conditions, and (4) ability to GP mineralization not associated with AMPA accumulation in the environment.

The analytical methodologies allowed us to detect sarcosine and AMPA as metabolites from glyphosate degradation by Penicillium 4A21. Nowadays, studies have been suggesting the existence of $\mathrm{C}-\mathrm{P}$ lyases that cleaves only the $\mathrm{C}-\mathrm{P}$ bond of GP to produce sarcosine and $\mathrm{Pi}$; the sarcosine pathway serves to utilize GP as a source of Pi (Selvapandiyan and Bhatnagar, 1994). However, the cleavage of the C-P bond in the GP molecule strongly depends on the concentrations of exogenous and endogenous $\mathrm{Pi}$, and is therefore usually induced under conditions of a phosphorus deficiency, which rarely occurs in natural environments (Bazot and Lebeau, 2008). In other well-known GP degradation pathway, the herbicide molecule is first attacked by the enzyme known as glyphosate oxidoreductase (GOR), which cleaves the C-N bond in GP molecules, yielding stoichiometric quantities of AMPA and glyoxylate (Klimek-Ochab et al., 2007).

AMPA resulting from glyphosate degradation can be a problem since AMPA can be considered toxic (Sviridov et al., 2012). However, previous work demonstrated that AMPA is an intermediary step in the degradation of glyphosate by fungi. Aspergillus oryzae A-F02 metabolizes AMPA into methylamine and then into other simple and less toxic products (Fu et al., 2017). AMPA can also be metabolized through phosphoformaldehyde transamination, mediated by aminotransferase enzymes. Then, phosphoformaldehyde is metabolized to formaldehyde for later metabolism (Sviridov et al., 2012; Kertesz et al., 1994). Thus, the complete study of the metabolic pathways of glyphosate degradation by the isolate Penicillium 4A21 should be deeply investigated.

The study has great biotechnological importance by presenting isolated and identified fungi from soil of the Amazon rainforest, with great potential for glyphosate herbicide degradation. The limitations include: a) necessity of taxonomy studies of Penicillium 4A21 isolate; b) study the ability of Penicillium 4A21 to degrade glyphosate "in situ"; c) detection and toxicity of biodegradation metabolites, and d) studies optimizing bioremediation process. 


\section{Conclusion}

In the present work, we found strains of fungi capable of using herbicide formulation as a source of phosphorus and others capable of growing more in the medium containing glyphosate as a phosphorous source than in the conventional medium. Some isolates highlighted in the present study have potential as glyphosate bioremediation agents.

\section{Acknowledgements}

The authors would like to recognize funding received from Fundação de Amparo à Pesquisa do Estado do Amazonas, Coordenação de Aperfeiçoamento de Pessoal de Nível Superior, and Conselho Nacional de Desenvolvimento Científico e Tecnológico - CNPp. We would like to thank Diego de Moura Rabelo and Felipe Moura Araújo da Silva, from Laboratório de Abertura de Amostra e Ensaios Químicos from Universidade do Amazonas, for their support with GC/MS analysis. In addition, we would like to thank John E. Hallsworth from Queen's University Belfast - Institute for Global Food Security, School of Biological Sciences, Belfast-UK for precious helping in writing and editing English of this manuscript.

\section{References}

ARFARITA, N., DJUHARI, D., PRASETYA, B. and IMAI, T., 2016. The application of Trichoderma viride strain frp 3 for biodegradation of glyphosate herbicide in contaminated land. Agrivita, vol. 38 , no. 3, pp. 275-281. http://dx.doi.org/10.17503/agrivita.v38i3.550.

ARFARITA, N., IMAI, T., KANNO, A., HIGUCHI, T., YAMAMOTO, K. and SEKINE, M., 2011. Screening of soil-born fungi from forest soil using glyphosate herbicide as the sole source of phosphorus. Journal of Water and Environment Technology, vol. 9, no. 4, pp. 391-400. http://dx.doi.org/10.2965/jwet.2011.391.

BATISTA, P.F., COSTA, A.C., MEGGUER, C.A., LIMA, J.S., SILVA, F.B., GUIMARÃES, D.S., ALMEIDA, G.M. and NASCIMENTO, K.J.T., 2018. Pouteria torta: a native species of the Brazilian Cerrado as a bioindicator of glyphosate action. Brazilian Journal of Biology = Revista Brasileira de Biologia, vol. 78, no. 2, pp. 296-305. http:// dx.doi.org/10.1590/1519-6984.07416. PMid:29069161.

BAZOT, S. and LEBEAU, T., 2008. Simultaneous mineralization of glyphosate and diuron by a consortium of three bacteria as freeand/or immobilized-cells formulations. Applied Microbiology and Biotechnology, vol. 77, no. 6, pp. 1351-1358. http://dx.doi org/10.1007/s00253-007-1259-3. PMid:18026726.

BOOPATHY, R., 2000. Factors limiting bioremediation technologies. Bioresource Technology, vol. 74, no. 1, pp. 63-67. http://dx.doi. org/10.1016/S0960-8524(99)00144-3.

CARRANZA, C.S., BARBERIS, C.L., CHIACCHIERA, S.M. and MAGNOLI, C.E., 2017. Assessment of growth of Aspergillus spp. from agricultural soils in the presence of glyphosate. Revista Argentina de Microbiologia, vol. 49, no. 4, pp. 384-393. http://dx.doi. org/10.1016/j.ram.2016.11.007. PMid:28882409.

CARRANZA, C.S., BARBERIS, C.L., CHIACCHIERA, S.M., DALCERO, A.M. and MAGNOLI, C.E., 2016. Isolation of culturable mycobiota from agricultural soils and determination of tolerance to glyphosate of nontoxigenic Aspergillus section Flavi strains. Journal of Environmental Science and Health. Part. B, Pesticides,
Food Contaminants, and Agricultural Wastes, vol. 51, no. 1, pp. 35-43. http://dx.doi.org/10.1080/03601234.2015.1080491. PMid:26549415.

CARRANZA, C.S., REGÑICOLI, J.P., ALUFFI, M.E., BENITO, N., CHIACCHIERA, S.M., BARBERIS, C.L. and MAGNOLI, C.E., 2019. Glyphosate in vitro removal and tolerance by Aspergillus oryzae in soil microcosms. International Journal of Environmental Science and Technology, vol. 16, no. 12, pp. 7673-7682. http://dx.doi. org/10.1007/s13762-019-02347-X.

FASSATIOWA, O., 1983. Microscopic fungi in technical microbiology. 1st ed. Warsaw: Scientific and Technical Publishing.

FU, G., CHEN, Y., LI, R.Y., YUAN, X.Q., LIU, C.M., LI, B. and WAN, Y., 2017. Pathway and rate-limiting step of glyphosate degradation by Aspergillus oryzae A-F02. Preparative Biochemistry $\mathcal{E}$ Biotechnology, vol. 47, no. 8, pp. 782-788. http://dx.doi.org/10 .1080/10826068.2017.1342260. PMid:28636478.

GASNIER, C., DUMONT, C., BENACHOUR, N., CLAIR, E., CHAGNON, M.C. and SÉRALINI, G.E., 2009. Glyphosate-based herbicides are toxic and endocrine disruptors in human cell lines. Toxicology, vol. 262, no. 3, pp. 184-191. http://dx.doi.org/10.1016/j. tox.2009.06.006. PMid:19539684.

GIESY, J.P., DOBSON, S. and SOLOMON, K.R., 2000. Ecotoxicological risk assessment for Roundup ${ }^{\circledR}$ herbicide. Reviews of Environmental Contamination and Toxicology, vol. 167, pp. 35120. http://dx.doi.org/10.1007/978-1-4612-1156-3_2.

KACZYŃSKI, P. and ŁOZOWICKA, B., 2015. Liquid chromatographic determination of glyphosate and aminomethylphosphonic acid residues in rapeseed with MS/MS detection or derivatization/ fluorescence detection. Open Chemistry, vol. 13, no. 1, pp. 10111019. http://dx.doi.org/10.1515/chem-2015-0107.

KERTESZ, M.A., COOK, A.M. and LEISINGER, T., 1994. Microbial metabolism of sulfurand phosphorus-containing xenobiotics. FEMS Microbiology Reviews, vol. 15, no. 2-3, pp. 195-215. http:// dx.doi.org/10.1111/j.1574-6976.1994.tb00135.x. PMid:7946467.

KLIMEK, M., LEJCZAK, B., KAFARSKI, P. and FORLANI, G., 2001. Metabolism of the phosphonate herbicide glyphosate by a non-nitrate-utilizing strain of Penicillium chrysogenum. Pest Management Science, vol. 57, no. 9, pp. 815-821. http://dx.doi. org/10.1002/ps.366. PMid:11561407.

KLIMEK-OCHAB, M., OBOJSKA, A., PICCO, A.M. and LEJCZAK, B., 2007. Isolation and characterization of two new microbial strains capable of degradation of the naturally occurring organophosphonate - Ciliatine. Biodegradation, vol. 18, no. 2, pp. 223-231. http://dx.doi.org/10.1007/s10532-006-9057-7. PMid: 16758270.

KRZYŚKO-LUPICKA, T., STROF, W., KUBŚ, K., SKORUPA, M., WIECZOREK, P., LEJCZAK, B. and KAFARSKI, P., 1997. The ability of soil-borne fungi to degrade organophosphonate carbon-tophosphorus bonds. Applied Microbiology and Biotechnology, vol. 48, no. 4, pp. 549-552. http://dx.doi.org/10.1007/ s002530051095. PMid:9390463.

MAQBOOL, Z., HUSSAIN, S., IMRAN, M., MAHMOOD, F., SHAHZAD, T., AHMED, Z., AZEEM, F. and MUZAMMIL, S., 2016. Perspectives of using fungi as bioresource for bioremediation of pesticides in the environment: a critical review. Environmental Science and Pollution Research International, vol. 23, no. 17, pp. 16904-16925. http://dx.doi.org/10.1007/s11356-016-7003-8. PMid:27272922.

MONSANTO, 2005 [viewed 27 August 2020]. Backgrounder glyphosate half-life in soil [online]. Washington, pp. 1-2. Available from: http://www.monsanto.com/glyphosate/documents/glyphosatehalf-life-in-soil.pdf

NAGARAJA, P. and BHASKARA, B.L., 2006. Sensitive spectrophotometric assessment of carbofuran using dapsone as a new chromogenic 
reagent in formulations and environmental samples. Eclética Química, vol. 31, no. 4, pp. 43-48. http://dx.doi.org/10.1590/ S0100-46702006000400006.

PITT, J. The genus Penicillium and its teleomorphic states Eupenicillium and Talaromyces. 1st ed. London: Academic Press, 1979.

RAPER, K.B. and FENNEL, D.I. The genus Aspergillus. Baltimore: W. and W. Company, 1965.

SELVAPANDIYAN, A. and BHATNAGAR, R.K., 1994. Isolation of a glyphosate-metabolising Pseudomonas: detection, partial purification and localisation of carbon-phosphorus lyase. Applied Microbiology and Biotechnology, vol. 40, no. 6, pp. 876882. http://dx.doi.org/10.1007/BF00173992.

SHARMA, A., KUMAR, V., SHAHZAD, B., TANVEER, M., SIDHU, G.P.S., HANDA, N., KOHLI, S.K., YADAV, P., BALI, A.S., PARIHAR, R.D., DAR, O.I., SINGH, K., JASROTIA, S., BAKSHI, P., RAMAKRISHNAN, M., KUMAR, S., BHARDWAJ, R. and THUKRAL, A.K., 2019. Worldwide pesticide usage and its impacts on ecosystem. SN Applied Sciences, vol. 1, no. 11, pp.1-16. http://dx.doi.org/10.1007/ s42452-019-1485-1.

SINGH, B. and SINGH, K., 2016. Microbial degradation of herbicides. Critical Reviews in Microbiology, vol. 42, no. 2, pp. 245-261. http:// dx.doi.org/10.3109/1040841X.2014.929564. PMid:25159042.

SVIRIDOV, A.V., SHUSHKOVA, T.V., ERMAKOVA, I.T., IVANOVA, E.V., EPIKTETOV, D.O. and LEONT'EVSKII, A.A., 2015. Microbial degradation of glyphosate herbicides. Прикладная Биохимия и Микробиология, vol. 51, no. 2, pp. 183-190. http://dx.doi. org/10.7868/S0555109915020221. PMid:26027353.
SVIRIDOV, A.V., SHUSHKOVA, T.V., ZELENKOVA, N.F., VINOKUROVA, N.G., MORGUNOV, I.G., ERMAKOVA, I.T. and LEONTIEVSKY, A.A., 2012. Distribution of glyphosate and methylphosphonate catabolism systems in soil bacteria Ochrobactrum anthropi and Achromobacter sp. Applied Microbiology and Biotechnology, vol. 93, no. 2, pp. 787-796. http://dx.doi.org/10.1007/s00253-0113485-y. PMid:21789492.

TORRE, L.A., BRAY, F., SIEGEL, R.L., FERLAY, J., LORTET-TIEULENT, J. and JEMAL, A., 2015. Global cancer statistics, 2012. CA: a Cancer Journal for Clinicians, vol. 65, no. 2, pp. 87-108. http://dx.doi. org/10.3322/caac.21262. PMid:25651787.

VAN BRUGGEN, A.H.C., HE, M.M., SHIN, K., MAI, V., JEONG, K.C., FINCKH, M.R. and MORRIS JUNIOR, J.G., 2018. Environmental and health effects of the herbicide glyphosate. The Science of the Total Environment, vol. 616-617, pp. 255-268. http://dx.doi. org/10.1016/j.scitotenv.2017.10.309. PMid:29117584.

WAUCHOPE, R.D., BUTTLER, T.M., HORNSBY, A.G., AUGUSTIJNBECKERS, P.W.M. and BURT, J.P., 1992. The SCS/ARS/CES pesticide properties database for environmental decision- making. Reviews of Environmental Contamination and Toxicology, vol. 123, pp. 1-155. http://dx.doi.org/10.1007/978-1-4612-28622_1. PMid:1732992.

ZHAN, H., FENG, Y., FAN, X. and CHEN, S., 2018. Recent advances in glyphosate biodegradation. Applied Microbiology and Biotechnology, vol. 102, no. 12, pp. 5033-5043. http://dx.doi. org/10.1007/s00253-018-9035-0. PMid:29705962. 